\title{
Pathogenicity of fungi colonising the soil after the cultivation of cover crops towards the seedlings of salsify Tragopogon porrifolius var. sativus (Gaterau) Br.
}

\author{
Elżbieta Patkowska ${ }^{1}$, Mirosław Konopiński ${ }^{2}$ \\ ${ }^{1}$ Department of Plant Pathology \\ University of Life Sciences in Lublin \\ Leszczyńskiego 7, 20-069 Lublin, Poland \\ e-mail: elzbieta.patkowska@ar.lublin.pl \\ ${ }^{2}$ Department of Soil Cultivation and Fertilization of Horticultural Plants \\ University of Life Sciences in Lublin \\ Leszczyńskiego 58, 20-068 Lublin, Poland \\ e-mail: miroslaw.konopinski@ar.lublin.pl
}

Key words: A. alternata, F. culmorum, F. oxysporum, $P$. irregulare, $R$. solani, $S$. sclerotiorum, harmfulness, salsify, pathogenicity test, cover crops

\begin{abstract}
The purpose of the present study was to conduct pathogenicity tests for salsify seedlings in a soil environment colonised by selected fungi species, after the cultivation of cover crops such as oats, common vetch and tancy phacelia. A growth chamber experiment used the seeds of 'Mamut' salsify and soil overgrown with Altenaria alternata, Fusarium culmorum, F. oxysporum, Pythium
\end{abstract}


irregulare, Rhizoctonia solani and Sclerotinia sclerotiorum. The pathogenicity of these microorganisms towards salsify seedlings was established on the basis of the grown plants, their health and a disease index calculated on the basis of a fivedegree scale. The examined isolates considerably weakened the emergence and health of salsify. Based on pathogenicity tests, such species as $R$. solani, $S$. sclerotiorum and $P$. irregulare were considered as the major cause of seedling necrosis and root rot of the plants of the Tragopogon porrifolius var. sativus. Among the studied soil-borne plant pathogens, the most pathogenic ones towards salsify seedlings proved to be the isolates of $R$. solani, $S$. sclerotiorum and $P$. irregulare, whereas the least harmful included A. alternata and F. culmorum.

\section{INTRODUCTION}

Salsify (Tragopogon porrifolius var. sativus), also called Oyster Plant, is a vegetable closely related to scorzonera. It comes from the Mediterranean area, where it was known as early as ancient times. In Europe it gained the greatest popularity in the $15^{\text {th }}$ and $16^{\text {th }}$ centuries, while in Poland it is still a vegetable that is little known and rarely cultivated. It belongs to the family of Asteraceae and is an annual or biennial plant (Hardenburg et al. 1986, Muller-Lemans 1991). The edible part of this plant is the yellowish or grayish thin taproot with white flesh and a taste similar to that of parsley root (Mencarelli 2007). Salsify is a valuable vegetable, considering both its taste and nutritious value. It contains large quantities of calcium, phosphorus, iron, carotene, vitamins $\left(\mathrm{B}_{1}, \mathrm{~B}_{2}, \mathrm{PP}\right.$ and $\left.\mathrm{C}\right)$ as well as inulin a glycoside that has a positive effect on human and animal organisms (Kierstan 1978, Mencarelli 2007). Inulin reduces the content of fats and the energetic value of food, at the same time improving the content of intestinal bacteria (Teeuwen et al. 1992, Lutomski 2001).

Due to the rather rare cultivation of salsify plants, the literature provides only scarce information concerning pathogens dangerous to this plant. As reported by Dellavalle et al. (1999), TSWV (Tomato spotted wilt virus) plays a considerable role in infecting the aboveground organs of salsify. In addition, the health of the aboveground parts of this vegetable is decreased by such fungi as Albugo tragopogonis, causing the blight of salsify (Mencarelli 2007), Erysiphe cichoracearum, causing powdery mildew (Namesny-Vellespir 1996), and Sclerotinia sclerotiorum, causing sclerotinia rot (Biller and Draper 2001). On the other hand, there is no information on the role of soil-borne fungi in infecting the underground parts of salsify. It is known that fungi colonizing the soil environment may constitute a considerable danger to different cultivated plants, including salsify, throughout the period of vegetation. These fungi as facultative pathogens inhibit the germination of seeds and cause the necrosis of seedlings and the root rot 
of older plants. Cover crops used for soil mulching may have an inhibiting effect on the formation of soil pathogen communities (Patkowska and Konopiński, unpublished data). Studies conducted earlier (Patkowska and Konopiński 2008) revealed that using oats, common vetch and tancy phacelia as cover crops considerably reduced the population of fungi pathogenic towards scorzonera.

The purpose of the present study was to conduct pathogenicity tests for salsify seedlings referring to different microorganism species colonizing the soil environment of this vegetable after the cultivation of cover crops.

\section{MATERIAL AND METHODS}

The experiment on the pathogenicity of soil-borne microorganisms towards salsify seedlings was conducted in a growth chamber. The seeds of 'Mamut' cultivar and soil overgrown with soil-borne plant pathogens, such as Altenaria alternata, Fusarium culmorum, F. oxysporum, Pythium irregulare, Rhizoctonia solani and Sclerotinia sclerotiorum, were used to establish the experiment. Those isolates came from the microbiological analysis of the soil conducted according to the method described by Martyniuk et al. (1991). The soil for the analysis was taken from the plough layer of the field where sasify was cultivated in the second 10-day period of June. The field experiment took into consideration soil mulching with intercrop cover crops such as oats, common vetch and tancy phacelia, which were ploughed over in autumn or in spring. A conventional cultivation of salsify, i.e. without any cover crops, was the control (Table 1).

The growth chamber experiment considered five randomly chosen isolates of each species of microorganisms, which were given the numbers from 1 to 5. Salsify seeds disinfected on the surface were sown into pots filled with soil overgrown with the mycelium of a single isolate of a given species. The control included salsify seedlings grown out of the seeds sown into sterile soil. 100 seeds were taken into consideration for each isolate and for the control. The infection mixture of plant pathogens used in the experiment was prepared according to Noll's method described in an earlier paper (Patkowska and Konopiński 2008). The conditions for seed germination and salsify growth in a growth chamber were similar to those described in an earlier experiment by Patkowska and Konopiński (2008). The temperature of the day, which lasted 16 hours, was $22-24^{\circ} \mathrm{C}$ (with irradiance of 27 $\mu \mathrm{mol} \mathrm{m} \mathrm{m}^{-2} \mathrm{~s}^{-1}$ ) and the temperature at night was $18-20^{\circ} \mathrm{C}$. The relative humidity of the air ranged from 70 to $85 \%$.

Four weeks after the seed sowing, the number of seedlings was determined and the percentage of plants with disease symptoms on the roots was established. The healthiness of the plants was estimated according to the five-degree scale given earlier for the seedlings of scorzonera: $0^{\circ}$ - no disease symptoms, $1^{\circ}-$ necrosis up 
to $10 \%$ of the root surface, $2^{\circ}$ - necrosis up to $25 \%$ of the root surface, $3^{\circ}-$ necrosis up to $50 \%$ of the root surface, $4^{\circ}$ - necrosis over $50 \%$ of the root surface (Patkowska and Konopiński 2008). The disease index was calculated according to McKinney's formula provided by Łacicowa (1969) and Patkowska and Konopiński (2008). Next, the plant material was submitted to a mycological analysis according to Koch's postulates.

The obtained results were statistically analyzed, and the significance of differences was established on the basis of Tukey's confidence intervals (Oktaba 1987).

\section{RESULTS AND DISCUSSION}

The microbiological analysis of the soil taken from the plough layer of particular combinations of the field experiment pointed to differentiated numbers of plant pathogens whose isolates were used in pathogenicity tests in the conditions of a growth chamber (Table 1). Fusarium oxysporum and Rhizoctonia solani proved to be most frequently isolated, and their mean proportion was $20.7 \%$ (Fig. 1). Fusarium culmorum and Pythium irregulare had the smallest proportions among the tested microorganisms (respectively, $11.0 \%$ and 14.1\%). The enumerated species are known for their ability to survive in the soil and for their polyphagous character, and hence, for being dangerous towards many vegetable species. As reported by Pięta and Kęsik (2006), those plant pathogens, and especially F. culmorum, constituted a serious threat towards onion plants. Studies conducted by Mazur et al. (2004) and Nawrocki (2005) also pointed to their harmfulness towards carrots and parsley. Blancard et al. (2005), on the other hand, provided information on the pathogenic character of the enumerated plant pathogens towards leaf chicory and endives.

Table 1. Microorganisms isolated from the soil

\begin{tabular}{|c|c|c|c|c|c|c|c|c|}
\hline \multirow{2}{*}{ Fungus species } & \multicolumn{7}{|c|}{ Experimental combination / Number of isolates } & \multirow{2}{*}{$\begin{array}{c}\text { Total } \\
\text { number }\end{array}$} \\
\hline & $1^{*}$ & 2 & 3 & 4 & 5 & 6 & 7 & \\
\hline Alternaria alternata (Fr.) Keissler & 2 & 2 & 4 & 4 & 7 & 10 & 12 & 41 \\
\hline Fusarium culmorum (W.G.Sm.) Sacc. & 1 & 1 & 2 & 3 & 4 & 5 & 9 & 25 \\
\hline Fusarium oxysporum Schl. & 2 & 2 & 5 & 7 & 8 & 9 & 14 & 47 \\
\hline Pythium irregulare Baisman & 1 & 2 & 3 & 4 & 5 & 6 & 11 & 32 \\
\hline Rhizoctonia solani Kühn & 2 & 4 & 5 & 5 & 8 & 10 & 13 & 47 \\
\hline Sclerotinia sclerotiorum Lib. de Bary. & 1 & 2 & 4 & 5 & 7 & 7 & 9 & 35 \\
\hline Total & 9 & 13 & 23 & 28 & 39 & 47 & 68 & 227 \\
\hline
\end{tabular}




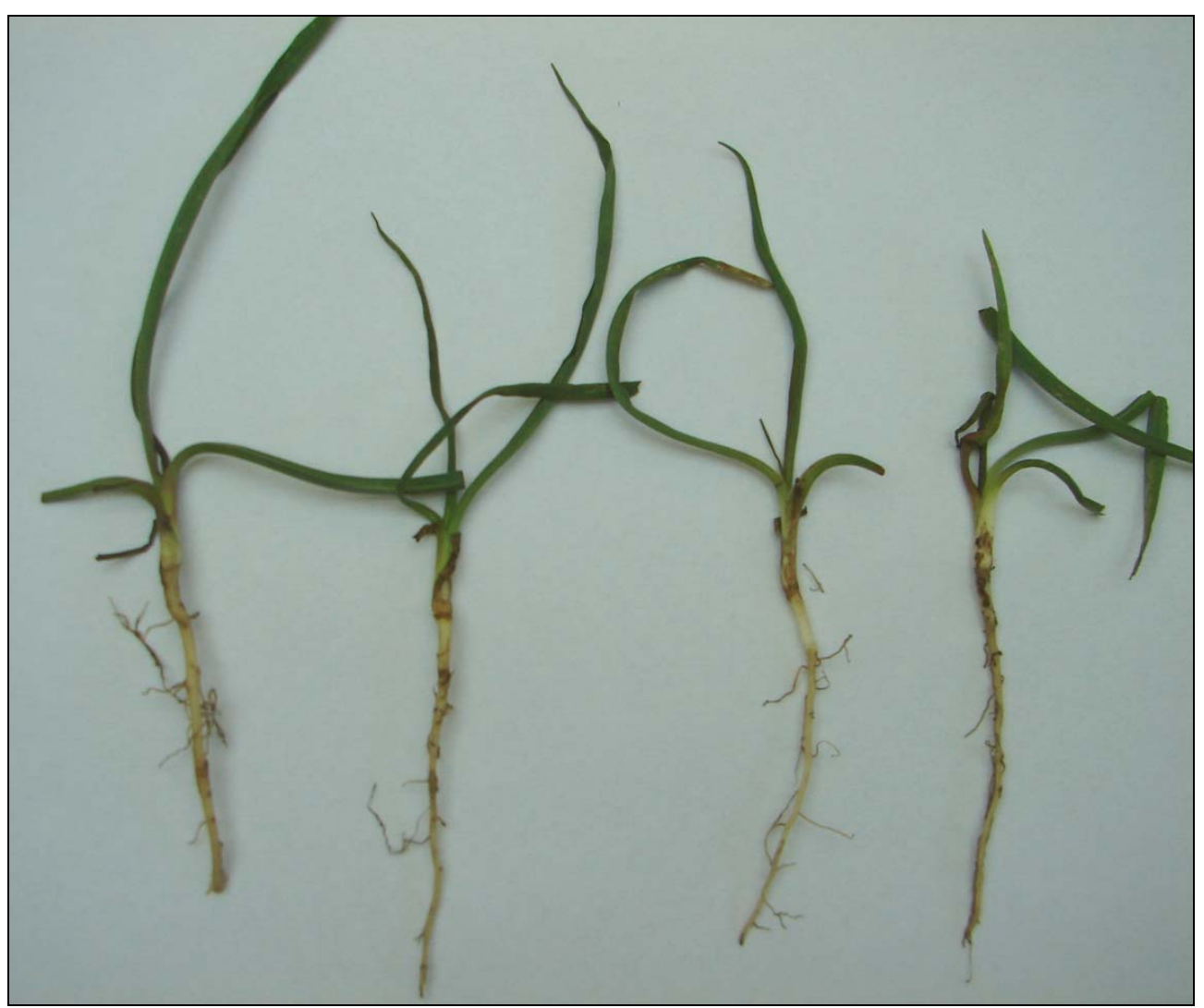

Fig. 2. The necrosis on roots of salsify seedlings (Phot. E. Patkowska)

The growth chamber experiment made it possible to determine the degree of pathogenicity of particular isolates of the studied microorganism species for salsify seedlings. This pathogenicity was established on the basis of the number of grown plants and their health (Tables 2 and 3). The poorest emergence was observed after inoculating the soil with the isolates of $P$. irregulare, $R$. solani and $S$. sclerotiorum (on average, 67.1, 60.1 and 61.6 seedlings). The best emergence occurred in the combinations with $A$. alternata and F. culmorum as respectively, from 72.5 to 97.0 and from 79.5 to 97.0 seedlings grew from the seeds, depending on the studied fungus isolate (Table 2). Slightly worse emergence of salsify was obtained after inoculating the soil with the species of $F$. oxysporum (on average, from 72.0 to 88.5 seedlings, depending on the studied fungus isolate). Earlier studies (Patkowska and Konopiński 2008) discovered that P. irregulare contributed to considerably worse emergence of scorzonera, and inoculation of the soil with the isolates of $S$. sclerotiorum caused the worst emergence of root chicory (Patkowska 
and Konopiński 2008, unpublished data). According to Biller and Draper (2001), fungus $S$. sclerotiorum also seriously threatened the field cultivation of salsify. On the other hand, the best emergence of scorzonera were also obtained after inoculating the soil with the isolates of A. alternata (Patkowska and Konopiński 2008).

Table 2. Mean number of salsify seedlings that emerged in particular experiment combinations

\begin{tabular}{lcccccc}
\hline Isolate & \multicolumn{5}{c}{ Pathogen species } \\
\cline { 2 - 7 } number & A. alternata & F. culmorum & F. oxysporum & P. irregulare & R. solani & S. sclerotiorum \\
\hline 1 & 97.0 & 88.0 & 88.5 & 74.5 & 72.5 & 67.5 \\
2 & 79.5 & 97.0 & 76.0 & 59.5 & 63.0 & 49.0 \\
3 & 91.0 & 79.5 & 81.0 & 64.0 & 55.0 & 66.0 \\
4 & 84.5 & 93.5 & 69.5 & 75.5 & 60.0 & 57.0 \\
5 & 72.5 & 80.0 & 72.0 & 62.0 & 50.0 & 68.5 \\
\hline Mean & 84.9 & 87.6 & 77.4 & 67.1 & 60.1 & 61.6 \\
\hline Control & 100 & 100 & 100 & 100 & 100 & 100 \\
\hline LSD & 9.05 & 7.87 & 8.91 & 9.17 & 10.93 & 12.01 \\
\hline
\end{tabular}

Table 3. Participation of infected salsify seedlings in particular experiment combinations (\%)

\begin{tabular}{lllllll}
\hline Isolate & \multicolumn{5}{c}{ Pathogen species } \\
\cline { 2 - 7 } number & A. alternata & F. culmorum & F. oxysporum & P. irregulare & R. solani & S. sclerotiorum \\
\hline 1 & 15.0 & 26.0 & 32.0 & 51.0 & 55.0 & 49.5 \\
2 & 10.5 & 19.5 & 26.5 & 43.5 & 49.5 & 37.5 \\
3 & 21.0 & 23.0 & 40.0 & 38.5 & 43.5 & 54.0 \\
4 & 16.5 & 15.5 & 34.5 & 54.0 & 51.5 & 44.0 \\
5 & 24.5 & 31.0 & 25.0 & 47.0 & 42.0 & 50.5 \\
\hline Mean & 17.5 & 23.0 & 31.6 & 46.8 & 48.3 & 47.1 \\
\hline Control & 0 & 0 & 0 & 0 & 0 & 0 \\
\hline LSD $_{0.05}$ & 4.51 & 5.01 & 6.32 & 7.86 & 4.76 & 4.63 \\
\hline
\end{tabular}

Table 4. Values of the disease index of salsify seedlings

\begin{tabular}{llllllc}
\hline $\begin{array}{l}\text { Isolate } \\
\text { number }\end{array}$ & \multicolumn{7}{c}{ Pathogen species } \\
\cline { 2 - 7 } & A. alternata & F. culmorum & F. oxysporum & P. irregulare & R. solani & S. sclerotiorum \\
\hline 1 & 5.8 & 11.4 & 16.4 & 24.5 & 26.5 & 30.3 \\
2 & 2.7 & 10.0 & 12.2 & 19.4 & 35.0 & 36.0 \\
3 & 8.5 & 9.5 & 20.8 & 29.6 & 40.2 & 25.2 \\
4 & 4.2 & 6.6 & 16.4 & 32.8 & 37.1 & 39.4 \\
5 & 6.5 & 12.4 & 21.6 & 34.4 & 34.0 & 24.8 \\
\hline Mean & 5.5 & 9.9 & 17.5 & 28.1 & 34.5 & 31.1 \\
\hline Control & 0 & 0 & 0 & 0 & 0 & 0 \\
\hline LSD $_{0.05}$ & 1.89 & 3.22 & 2.01 & 3.57 & 4.31 & 4.36 \\
\hline
\end{tabular}


[\%]

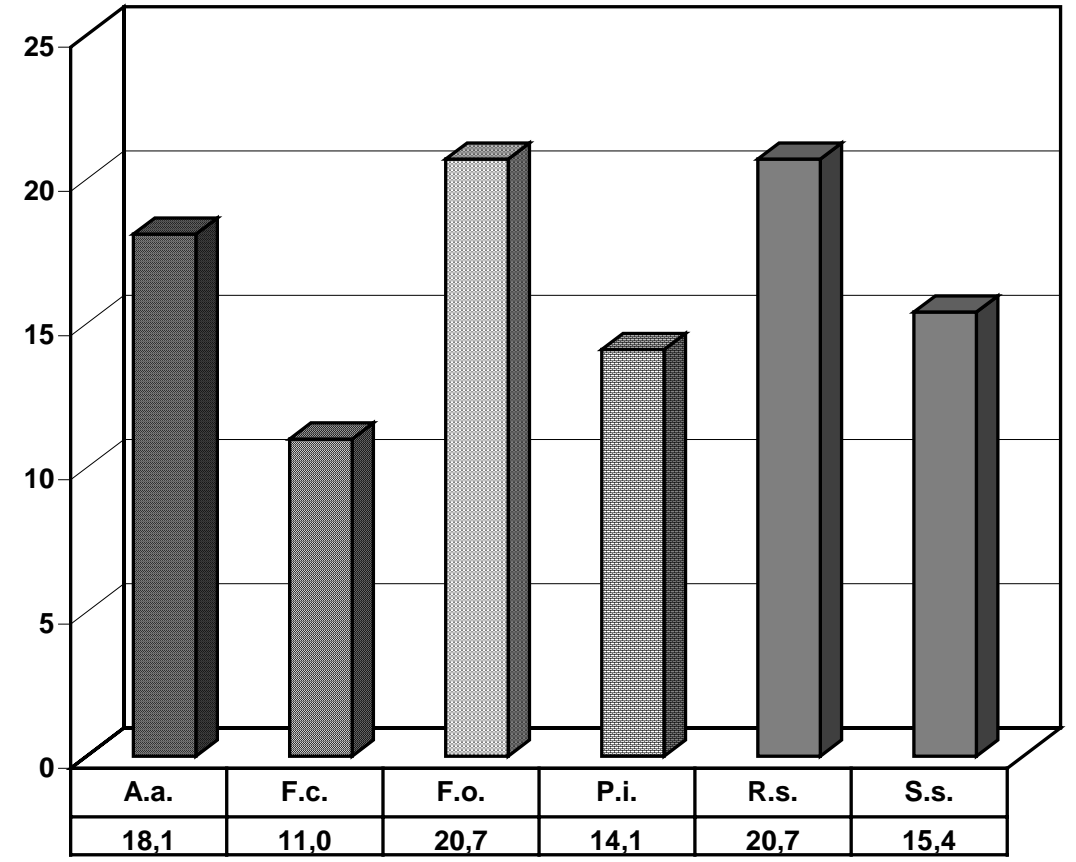

Fig. 1. Participation of selected phytopathogens isolated from the soil A.a. - A. alternata, F.c. $-F$. culmorum, F.o. - F. oxysporum, P.i. - P. irregulare, R.s. - R. solani, S.s. - S. sclerotiorum

Particular experimental combinations included the seedlings with inhibited growth, with necrotic symptoms on the roots (Fig. 2). The number of diseased seedlings was differentiated and found to be related to the studied isolate within a given plant pathogen species. The greatest number of diseased seedlings were obtained in combinations with $R$. solani, S. sclerotiorum and P. irregulare, as their proportion was, respectively, $48.3 \%, 47.1 \%$ and $46.8 \%$, on average (Table 3 ). The smallest number of diseased salsify seedlings grew from the seeds sown into the soil infected with $A$. alternata, and their proportion ranged from $10.5 \%$ to $24.5 \%$, depending on the examined isolate. The germinating salsify seeds and seedling roots were infected by the isolates of $F$. culmorum and $F$. oxysporum in a slightly greater degree. The proportion of diseased seedlings in those combinations of the experiment ranged, respectively, from 15.5 to $31.0 \%$ and from 25.0 to $40.0 \%$ (Table 3). In the control combination, healthy seedlings were obtained from all salsify seeds. As reported by Plentinger and Lamers (2000), infection of leaf chicory by $S$. sclerotiorum, Pythium sp. and Phytophthora sp. considerably decreased the health of this plant. According to Pięta and Kęsik (2006), fungi from the Fusarium genus also proved pathogenic towards onion seedlings. On the other hand, the isolates of $P$. irregulare proved to be the most pathogenic towards 
scorzonera seedlings, while A. alternata was the least pathogenic (Patkowska and Konopiński 2008).

The value of the disease index for salsify seedlings, calculated on the basis of a five-degree scale, ranged from 2.7 to 40.2 in particular experimental combinations (Table 4). The smallest value of the disease index was characteristic of the examined seedlings grown in the combinations with A. alternata or $F$. culmorum (respectively, from 2.7 to 8.5 and from 6.6 to 12.4 , depending on the examined isolate). Slightly higher values of the index of seedling infection were found after inoculating the soil with the isolates of $F$. oxysporum (from 12.2 to 21.6). On the other hand, the highest index of salsify seedling infection was observed in combinations with $R$. solani, $S$. sclerotiorum and $P$. irregulare, i.e. 34.5, 31.1 and 28.1, respectively (Table 4). Studies by Biller and Draper (2001) also pointed to the considerable pathogenicity of S. sclerotiorum towards salsify plants. On the other hand, Mazur et al. (2004) informed about the pathogenic character of Altenaria spp. towards carrots, parsley and celery. In addition, Nawrocki (2005) discovered a considerable pathogenicity of $F$. oxysporum, $P$. irregulare and $R$. solani towards the seedlings of parsley cultivated in field or greenhouse conditions.

Reisolation from the infected tissues of salsify carried out according to Koch's postulates confirmed the colonization of those plants by Altenaria alternata, Fusarium culmorum, F. oxysporum, Pythium irregulare, Rhizoctonia solani and Sclerotinia sclerotiorum with the morphological features identical to those of isolates used in inoculation.

\section{CONCLUSIONS}

1. It was discovered that soil-borne plant pathogens constitute a significant threat towards the seedlings and older plants of salsifies, as they considerably weaken the emergence and health of this plant.

2. Such species as Rhizoctonia solani, Sclerotinia sclerotiorum and Pythium irregulare could be considered the main cause of seedling blight and root rot of Tragopogon porrifolius var. sativus.

3. Among the studied species of soil microorganisms, the isolates of $R$. solani, $S$. sclerotiorum and $P$. irregulare proved to be the most pathogenic towards salsify seedlings, whereas Altenaria alternata and Fusarium culmorum were the least harmful. 


\section{ACKNOWLEDGEMENTS}

The studies were financed by the Ministry of Science and Higher Education, grant No. 2 P06 R 01429

\section{REFERENCES}

BILLER CH.R., DRAPER M.A., 2001. White mold of vegetables and ornamentals in the home garden. NDSU Extension Circular (Rev.) 701: 231-238.

BlanCARD D., Lot H., MaisonNeUve B., 2005. A colour atlas of diseases of lettuce and related salad crops: observation, biology and control. London, UK: Manson Publishing Ltd.: 376 pp.

Dellavale G., Ciuffo M., Roggero P., Lisa V., Minuto A., Minuto G., RAPETTI S., 1999. Tospoviruses in Delphinium sp., gazania, marguerite, celery, Tragopogon porrifolius and Solanum rantonnetii in Liguria (nothern Italy). Informatore Fitopatologico 49(9): 63-64.

HARDENBURG R.E., WATADA A.E., WANG C.Y., 1986. Salsify. In: USDA Hndbk. 66: $69 \mathrm{pp}$.

KIERSTAN M.P.J., 1978. Production of fructose syrups from inulin-containing plants [Jerusalem artichoke, chicory, salsify extracts]. Biotech. Bioeng. 20: 447-450.

LUTOMSKI J., 2001. Topinulin - pogoda dla zdrowia. Postępy Fitoterapii. Wyd. Medyczne, Borgis 5 (1/2001): 30-31.

ŁACICOWA B., 1969. Metoda laboratoryjna szybkiej oceny odporności jęczmienia na Helminthosporium sativum P.K. et B. Biul. IHAR 3-4: 61-62.

MarTyniUK S., MasiaK D., Stachyra A., MYŚKóW W., 1991. Populacje drobnoustrojów strefy korzeniowej różnych traw i ich antagonizm w stosunku do Gaeumannomyces graminis var. tritici. Pam. Puł. Pr. IUNG, 98: 139-144.

MAZUR S., NAWROCKI J., GAWĘDA M., 2004. Susceptibility of three carrot cultivars to Alternaria leaf blight in field growing conditions. Folia Univ. Agr. Stetin., Agr. 239(95): 249-252.

MENCARELLI F., 2007. Salsify. http://usna.usda.gov/hb66/125salsify.pdf.

MULLER-LEMANS H., 1991. Tragopogon porrifolius, die Haferwurzel - eine Literaturübersicht. Gartenbauwissensshaft 2: 53-58.

NAMESNY-VALLESPIR A., 1996. Vegetables postharvest. Volume II - Bulbs, tubers, rhizomes. Compendio de Horticultura II: 294 pp.

NAWROCKI J., 2005. Podatność siewek różnych odmian pietruszki korzeniowej na porażenie przez patogeny grzybowe. Acta Agrobot. 58(2): 163-170. 
OKTABA W., 1987. Metody statystyki matematycznej w doświadczalnictwie. PWN, Warszawa.

PATKOWSKA E., KONOPIŃSKI M., 2008. Pathogenicity of selected soil-borne microorganisms for scorzonera seedlings (Scorzonera hispanica L.). Folia Hort. 20/1: 31-42.

PIĘTA D., KĘSIK T., 2006. Pathogenic soil-borne fungi of onion cultivated after cover crops: spring rye and common vetch. Acta Sci. Pol., Hort. Cult. 5(1): 71-78.

PLENTINGER M.C., LAMERS J.G., 2000. Biological control of rot caused by Sclerotinia in witloof chicory. PAV Bulletin Vollegrondsgroenteteelt: 20-22.

TEeuwen H., TONE M., VANDORPE J., 1992. Inulin: A versatile ancient food ingredient rediscovered. Int. Food Ingr. 5: 10-14.

\section{PATOGENICZNOŚĆ GRZYBÓW ZASIEDLAJĄCYCH GLEBĘ PO UPRAWIE ROŚLIN OKRYWOWYCH DLA SIEWEK SALSEFII TRAGOPOGON PORRIFOLIUS VAR. SATIVUS (GATERAU) BR.}

Streszczenie: Celem prezentowanych badań było przeprowadzenie testów patogeniczności dla siewek salsefii wybranych gatunków grzybów zasiedlających środowisko glebowe tego warzywa po uprawie roślin okrywowych, takich jak: owies, wyka siewna i facelia. W doświadczeniu fitotronowym wykorzystano nasiona salsefii odm. 'Mamut' oraz ziemię ogrodową, przerośniętą izolatami Alternaria alternata, Fusarium culmorum, F. oxysporum, Pythium irregulare, Rhizoctonia solani i Sclerotinia sclerotiorum. Patogeniczność tych mikroorganizmów dla siewek salsefii określono na podstawie liczby wyrosłych roślin, ich zdrowotności oraz indeksu porażenia obliczonego na podstawie pięciostopniowej skali. Badane izolaty znacznie osłabiły wschody oraz zdrowotność salsefii. Na podstawie testów patogeniczności, gatunki takie jak $R$. solani, $S$. sclerotiorum i $P$. irregulare uznano za główną przyczynę zgorzeli siewek oraz zgniliznę korzeni roślin Tragopogon porrifolius var. sativus. Spośród badanych fitopatogenów odglebowych najbardziej patogenicznymi dla siewek salsefii okazały się izolaty $R$. solani, S. sclerotiorum i $P$. irregulare, a najmniej szkodliwymi A. alternata i F. culmorum. 